\title{
Jak zvýšit u žáků zájem o technické a učební obory? - historická analogie
}

\author{
Kamil Janiš ml. \\ Slezská univerzita v Opavě, Fakulta veřejných politik v Opavě, Ústav pedagogických \\ a psychologických věd
}

Již několikrát jsem ve svých příspěvcích poukázal na to, že prakticky každé pedagogické téma, které považujeme za aktuální, můžeme nalézt $\mathrm{v}$ až „obludně“ identické podobě v dobách minulých. Jedním z mých posledních příspěvků je diskuzní příspěvek ke kariérnímu řádu učitelů (návrh z roku 2017) v komparaci s vyhláškou Ministerstva školství a národní osvěty z roku 1920 (Janiš ml., 2018). Někdy to skutečně připomíná tvorbu pomocí „metody ctrl+c a ctrl+v“. V poslední době způsobila „bouři ve sklenici vody“ diskuze o obědech zdarma. Opět můžeme nalézt historickou paralelu např ve školských zákonech Rakouska-Uherska z konce 19. století, ale i v dokumentech jiných.

Nyní se do popředí dostala diskuze o problematice, která se týká struktury středních škol; kdo může jít studovat maturitní obory, koho „společnost“ (průmysl) potřebuje apod. Cílem př́íspěvku je danou problematiku konfrontovat diskuzní formou s vybranými historickými texty.

Příspěvek je rozdělen do dvou částí, z nichž první reflektuje určitý myšlenkový proud, který vychází $\mathrm{z}$ „vnější“ organizace školství a je orientován na jistou selekci žáků dle potřebnosti určitých profesí na základě poptávky trhu práce. Druhá část je zaměřena na reflexi „vnitřního“ zásahu do organizace školství, resp. úpravy obsahu výuky a výchovy, avšak opět dle potřebnosti určitých profesí na základě poptávky trhu práce.

Oba myšlenkové proudy, které se vynořují ve stále stejných podobách, lze považovat za naprosto legitimní, ale hlouběji historicky nereflektované.

\section{$1 \quad$ Kdo má jít studovat?}

Velmi často se prezentujeme jako národ J. A. Komenského (1592-1670), prezentujeme jeho didaktické zásady, výňatky z jeho díla apod. $V$ jeho díle lze nalézt několik myšlenek, které se vztahují k problematice, která rezonuje v politicko-odborných diskuzích posledních dní, a to k problematice tzv. cut-off 
score, tedy centrálně stanovené minimální hranice pro přijetí na střední školu. Velmi zjednodušeně má určit, kdo může a kdo nemůže získat maturitu.

Ačkoliv Komenský považoval prakticky všechny děti za vzdělavatelné, uvědomoval si, že absolvování všech stupňủ škol není pro každého.

Na úvod je nutné poznamenat, že níže uvedené pasáže se vztahují k určitému stupni školy - akademii, a tedy v podstatě k vysokým školám, ale k analogické aplikaci jsou plně využitelné.

Práce akademie půjde snáze a zdárněji, předně, budou-li tam posíláni jinoši vybraného nadání, výkvět lidstva, a ostatní budou odkázáni k pluhu, k řemeslům a obchodu, pokud jsou pro to zrozeni. (Komenský, 1930, s. 292-293)

Ve výše uvedeném textu spatřujeme explicitně zmíněnou selekci na základě studijních předpokladů žáků, která je i v současné době zejména zřizovateli středních škol (kraji) považována za žádoucí, resp. potřebnou. ${ }^{1}$ $\mathrm{K}$ dalším komentářům a diskuzi je potřebné doplnit další vybrané pasáže Komenského díla.

Za druhé, věnuje-li se každý tomu studiu, kterému - jak to lze poznati z určitých známek - jej určila přirozenost. Nebot' jako pudem přirozenosti jeden stává se lepším hudebníkem, básníkem, řečníkem, fysikem atd. než druhý: tak jest jeden schopnější pro theologii, lékařství a právnictví než druhý. Ale v tom se chybuje př́liš často, když chceme libovolně z každého dřeva nadělati fládru, nedbajíce přirozené náklonnosti. Tím se stává, že ženouce se na to neb ono studium proti vůli Minervině neprovedeme v něm nic chvály hodného a často provedeme více v kterémkoli díle vedlejším než ve vlastním povolání. Bylo by tedy radno, aby před odchodem z klasické školy správcové škol uspořádali nějakou zkoušku, kdež by prozkoumáno bylo nadání žákủ, a aby podle rozhodnutí správců bylo stanoveno, kteří jinoši by měli býti posláni na akademii a kteř́ určeni k jinému povolání životnímu; taktéž kteří by se měli obrátiti k studiu theologie, státních věd nebo lékařství atd. bud' podle toho, jak se u nich jeví přirozená náklonnost, nebo jak toho vyžaduje potřeba církve a státu. (Komenský, 1930, s. 293)

Ve druhé citované pasáži lze spatřit dvě linie myšlenek autora. První je, že se skutečně ne každý může stát „vším“. Každý má schopnosti, dovednosti, znalosti apod. na různorodé úrovni a měl by je umět objektivně zhodnotit a dle toho si vybrat své další vzdělávání. Významně by se měli v této oblasti

1 http://www.asociacekraju.cz/novinky/vsechny-kraje-znovu-zadaji-ministerstvo-skolstvio-bezodkladne-reseni-situace-na-strednich-skolach-1.html 
angažovat i rodiče žáka. Obecně však lze jednoznačně souhlasit s tím, že ne každý může dosáhnout na nejvyšší stupně vzdělání. Ale zároveň je nutné si položit několik otázek: Věděli jsem v 15 letech, čím chceme být?² Reflektují naše výsledky ze základní školy naše výsledky ze škol středních? Jak ke studiu přistoupí žák, kterému školu vybere „systém"? Dokáží rodiče sami zhodnotit schopnosti a dovednosti svých dětí? a jiné. Vliv rodičů je $\mathrm{v}$ předmětné souvislosti spíše v oblasti jakéhosi transgeneračního přenosu³, což je skutečnost všeobecně známá, ale edukovat ${ }^{4}$ a v některých případech reedukovat rodiče skrze základní školu je minimálně problematické až nemožné. Dostáváme se tak do problematiky rozvoje možností komunikace mezi rodinou a školou.

Druhá myšlenková linie citované pasáže se týká dle mého mnohem nebezpečnější oblasti. Je zmiňována potřeba státu, což je možná v současnosti nejvíce diskutovaná skutečnost v souvislosti se strukturou středních škol, s obory (dnes programy) na vysokých školách a s tím, jací absolventi resp. jaké profese chybí. Z jakého důvodu tuto oblast považuji za nebezpečnější? Stát i kraje mají možnost regulovat strukturu středního a vysokého školství, a to prostřednictvím financování. Zavřít (zrušit) školu je relativně jednoduché, ale otevř́t novou již nikoliv. Zároveň se při tomto rozhodování vychází z dat, která platí pro „tady a ted'“, př́ip. pro blízkou budoucnost, a vzdělávací systém (myšleno $\mathrm{z}$ hlediska struktury oborů) nelze neustále měnit. Změna se především projeví až v době, kdy vše může být naprosto jinak - za pět, šest, sedm nebo 10 let. Nepopírám, že by školy (základní, střední, vyšší odborné, vysoké) neměly reagovat na aktuální situaci. Jednou stranou mince je, kolik absolventů daný obor (program) „vyprodukuje“, a druhou stranou mince je, kolik jich $\mathrm{v}$ absolvovaném oboru (programu) začne pracovat. $\mathrm{V}$ případě základních škol se primárně jedná o modifikaci výuky např. zapojením principů zážitkové pedagogiky do výuky.

Zároveň se diskuze nad strukturou oborů (programů) zpravidla vždy „Zvrhne" do diskuze technické/př́rodovědné vs. humanitní obory (programy).

Níže citovaná pasáž navazuje na předchozí odstavce vztahující se k odbornému vzdělávání a akcentuje důležitost všeobecného vzdělání a vzdělávání,

Tím se částečně vracíme k Václavu Příhodovi (1889-1979).

Není myšleno jen a pouze $\mathrm{v}$ rovině - máma učitelka $=$ dcera učitelka, ale $\mathrm{v}$ širší rovině zahrnující i faktory sociální situace rodiny, vzorců chování apod.

4 Není myšleno, že je obtížné či nemožné rodiče informovat. To samozřejmě základní školy činí. 
které i v současnosti bývá podceňováno, resp. stavěno do opozice se vzděláním a vzděláváním odborným:

Za třetí bude radno ke všestrannosti povzbuzovati jinochy vynikajícího nadání, aby nenastal nedostatek lidí, kteří jsou mnohoučení a vševědoucí. (Komenský, 1930, s. 293).

Poslední část citovaného Komenského díla se týká problematiky, která rovněž byla diskutována, trápí střední i vysoké školy, ale je $v$ podstatě neřešitelná, jelikož se dostává do střetu s hospodářskými zájmy společnosti.

Avšak bude třeba pečovati o to, aby akademie vychovávaly pouze pilné, mravné a dovedné žáky, ale aby netrpěly lžistudentů, kteří zahálkou a hýřivým životem mrhají jmění i čas, dávajíce tak ostatním škodlivý př́íklad. Tak tam, kde nebude moru, nebude nákazy, když všichni budou se horlivě obírati svými úkoly. (Komenský, 1930, s. 293-294).

Slovem „lžistudent“ lze v současném kontextu označit studenty vysokých škol, kteří jsou ke studiu zapsáni (po určitou dobu) jen a pouze z důvodu určitých sociálních a ekonomických výhod, které vyplývají z toho, že mají status studenta. Tím odčerpávají nemalé finanční prostředky, kterou jsou v podstatě „,vyhozeny z okna“. Dále tak lze označit studenty vysokých a středních škol, kteř́i sice studovat chtějí, ale jejich prrístup ke studiu je takový, že danou školu nedokončí.

V širším kontextu by daný pojem mohl zahrnovat i studenty, kteří po určité době zjistili, že jejich volba zaměření školy, a tedy i studijního oboru (progra$\mathrm{mu}$ ), byla chybou. Není výjimkou, že výběr školy je v některých případech „motivován“ např tím, že na škole studují či budou studovat kamarádi, spolužáci apod. Je však nutné rozlišit, zda student svým nezodpovědným přístupem ke studiu selhal, přecenil své schopnosti a dovednosti nebo skutečně zjistil, že $\mathrm{v}$ daném oboru nechce profesně působit. Ekonomické důsledky výše uvedeného jsou bezpochyby nemalé. I když jsem nenalezl žádný konkrétní finanční údaj, jedná se o údaj vyčíslitelný.

Časové rozpětí mezi původním Komenského textem a současností dokazuje, že se pohybujeme $v$ určitém začarovaném kruhu problematiky, která pro nás rozhodně není nová, ale je prozatím stále neřešitelná bez direktivních regulačních opatření, jenž by však byla kontraproduktivní. 


\section{Jak žáky motivovat a přivést žáky $k$ „technice“?}

Výše jsem uvedl, že direktivní regulační opatření by byla kontraproduktivní, a tak nezbývá než žáky motivovat vnitřně. Vnější motivace prostřednictvím stipendií apod. se ukázala jako neúčinná. Prakticky všechny kraje v České republice mají vypsány stipendijní programy pro studenty „učňovských“ oborů, avšak data Českého statistického úřadu potvrzují, že počet studentů oborů s výučním listem mezi školními roky 2006/2007 a 2016/2017 poklesl o $32 \%$. . Zájem o studium nelze vynutit finančními stimuly.

Druhá část mého diskuzního příspěvku bude zaměřena na rozvoj polytechnického vzdělávání, a to formou velmi volné komparace textů z let 1951 a 2019, která opět dokazuje bloudění v začarovaném kruhu. Objektivně je nutné uznat, že úplná komparace by musela zahrnovat komplexní historicko-politicko-hospodářský popis rámce společnosti $\mathrm{v}$ čase vzniku jednotlivých textů. Proto je zaměřena pouze na obecné fragmenty důležitosti a potřebnosti polytechnického vzdělávání a vzdělání. ${ }^{6}$ Text z roku 1951 je souhrnným článkem jakéhosi workshopu (či kulatého stolu), kde byla zástupci zainteresovaných institucí (ministerstvo pracovních sil, školy, technické muzeum, VÚP aj.) vedena diskuze k hlavnímu referátu M. Veselého o podpoře polytechnického vzdělávání. Důvodem realizace byla tehdejší orientace československého hospodářství na těžký průmysl, mechanizace např. v zemědělství, elektrifikace apod., a tedy potřeba technicky vzdělaných lidí a lidí pracujících v tehdy preferovaných oborech těžkého průmyslu (hornictví, hutnictví). Text z roku 2019 je věnován vybrané povinné intervenční oblasti (polytechnickému vzdělávání) v rámci národního projektu Podpora krajského akčního plánování (P-KAP), který realizuje Národní ústav pro vzdělávání. Celý projekt má pomoci koordinovat vzdělávací politiku na úrovni státu, školství a krajů. ${ }^{7}$

Filozofii polytechnického vzdělávání lze odvodit z konceptu STEM. Koncept STEM vznikl v USA v 90. letech minulého století pro označení vzdělávání v oborech př́rodní vědy (Science), techniky (Technology) a technologie (Engineering) a matematiky (Matematics). Přirozená blízkost a př́ibuznost těchto oborů vybízela $\mathrm{k}$ tomu, aby byly spojeny pod jedním označením. $\mathrm{V}$ průběhu prvního desetiletí 21. století i v současnosti je této oblasti věnována stále větší pozornost

\footnotetext{
https://www.czso.cz/csu/czso/skoly-a-skolska-zarizeni

6 U článku z roku 1951 je nutné filtrovat užívaný slovník, slovní obraty a ideologické zaměření. Rámcový obsah a význam je ve své podstatě nezměněný (srov. Janiš ml., 2014).

7 Blíže viz http://www.nuv.cz/p-kap/projekt-1.
} 
ve Spojených státech i v Evropě zejména proto, že v těchto oborech povážlivě ubývá studentů a sílí jejich nezájem o studium předmětů STEM. Obory v oblasti STEM jsou přitom chápány jako rozhodující pro rozvoj a růst ekonomik, pro udržení konkurenceschopnosti a trvale udržitelného rozvoje. V konceptu STEM je zřetelná orientace na vzdělávání, které je v konceptu vnímáno jako podstatný faktor. Stále častěji je STEM vnímán jako komplex vzájemných implikací mezi uvedenými oblastmi.

Hlavním smyslem konceptu je příprava absolventů těchto oborů, zajištění pracovní síly $\mathrm{v}$ perspektivních oblastech. Tomu logicky odpovídá podpora studijních oborů na středoškolské i vysokoškolské úrovni, které mají potenciál takovéto absolventy připravit (vychovat). Nejde tedy ani tak o předměty samotné. Jako další cíle konceptu jsou uváděny: zvýšení podílu žen zaměstnaných v oborech STEM a kultivace nejlepších odborníku (expertů) pro obory STEM. (Podpora polytechnického vzdělávání: pojetí tematické oblasti v projektu P-KAP [online])

Ve své podstatě je koncept STEM popsán i v článku Meisnera a Veselého (1951), jehož pasáže jsou níže citovány:

Hlavním článkem $\mathrm{k}$ dosažení cílů socialismu je člověk a jeho uvědomělá snaha zdokonalovat výrobní prostředky, zlepšovat organizaci práce, zavádět mechanizaci, šetřit materiálem a energií, snižovat výrobní časy, snižovat a odstraňovat produktivní náklady, překonávat zastaralé technické normy, vzdělávat se atd.

Tato snaha, rozšířená na miliony lidí, je s to nejen splnit, ale i překonat úkoly, které jsme si v 5LP dali.

Tyto velké úkoly žádají od školy a od naší výchovy, aby vytvářela lidi, kteří již nebudou podléhat přežitkům kapitalismu, kteří se rychle zařadí na svém pracovišti, kteří budou vzorem tvořivosti, houževnatosti, bohatě rozvinutých rozumových schopností a veliké aktivní vůle uplatnit se co nejvíce při budování. Naše škola musí vychovávat pracovníky, kteří nejen rychle přejmou zkušenosti od svých spoludělníků a mistrů, naučí se ovládat stroje, u nichž budou pracovat, ale kteří též budou rozvíjet převzaté zkušenosti rychle a pohotově dál, neustrnou, půjdou dopředu, budou samostatně jednat a správně řešit úkoly, které před ně život a povolání postaví. Naše škola musí vychovat vzdělaného člověka, který pochopil význam vzdělání pro práci ve výrobě a význam produktivní práce, který proto chce stát v socialistickém budování na místě, kde to společnost nejvíce potřebuje, a dává všechny svoje síly k zajištění větší produktivity práce.

Vědomosti a činnosti, které se do pojmu polytechnického vzdělání mohou zařadit, musí mít nutně tyto znaky: 
1. musí žáky poučovat o výrobě na základě theoretických poznatků, získaných v systému vědních poznatků;

2. v práci na úkolech, při jejichž řešení se uplatňují rovněž theoretické poznatky, musí žáci nabývat znalostí v ovládání základních výrobních nástrojů, tyto poznatky musí být těsně spjaty $s$ naší výrobou, at' průmyslovou nebo zemědělskou, a musí svými výsledky sloužit $\mathrm{k}$ splnění konkrétní potřeby žákovy, školy a všeobecné potřeby veřejnosti. (Veselý, in Meisner \& Veselý, 1951, s. 611-612)

Dále se v př́íspěvku Meisnera a Veselého (1951) dozvídáme prakticky totožné informace jako v textu s názvem: Podpora polytechnického vzdělávání: pojetí tematické oblasti v projektu $P-K A P$, a to včetně důrazu kladeného na environmentální výuku.

Znovu zdůrazňuji, že je nutné filtrovat ideologické zaměření, popř. se věnovat substituci slov, např. budování socialismu vs. trvale udržitelný rozvoj.

Uvedenými citacemi, jsem chtěl opět dokázat, že ke každému pedagogickému tématu existuje historická paralela, která nás $\mathrm{v}$ některých případech vede k otázkám typu „proč nebyla reflektována“. I v této bizarní komparaci spatřujeme bloudění v kruhu - změnila se politická situace (naštěstí), vzdělanostní struktura společnosti, ale nezměnily se formy, prostředky (některé materiální ano) a metody výchovy a vzdělávání, které by měly být uplatněny při podpoře polytechnického vzdělávání.

Vracíme se tak do první poloviny diskuzního příspěvku, kde jsme se věnovali něčemu, co tu částečně „bylo“. Třeba se za 15 let vrátíme k současnému stavu. Predikovat vývoj školství a provádět direktivní změny neumí v současnosti MŠMT ČR, což je mimo jiné uvedeno v dokumentu Podpora polytechnického vzdělávání: pojetí tematické oblasti v projektu P-KAP:

Vývoj oblasti polytechnického vzdělávání lze jen těžko v současné době predikovat. Důvodem je ne zcela konkrétní vymezení polytechnického vzdělávání ze strany MŠMT. Z definic uvedených MŠMT nevyplývá specifičnost polytechnického vzdělávání, ale pouze v souladu s konceptem STEM snaha o integraci několika oblastí vzdělávání, ve kterých je technické vzdělávání postaveno na úroveň ostatních oblastí. Tento stav se však neshoduje s kurikulárními dokumenty, kde je technické i environmentální vzdělávání zahrnuto do oblasti př́rodovědného vzdělávání. Zároveň nejsou jasné další kroky MŠMT, kterými bude polytechnické vzdělávání systematicky podporovat. ${ }^{8}$

8 http://www.nuv.cz/uploads/P_KAP/ke_stazeni/pojeti_decizni_sfera/PTV_IV_podrobne_ pojeti_oblasti_intervence.pdf 


\section{Závěr}

Diskuzní příspěvek odkazuje na skutečnost, že propojení myšlenek ze 17. století, poloviny 20. století a současnosti je reálné a na každý pedagogický problém se lze podívat nejen didakticky, metodicky, psychologicky, prostřednictvím zahraničních zkušeností, př́kladů dobré praxe apod., ale i prostřednictvím dějin výchovy. Je mi jako autorovi jasné, že nikdo nepůjde oprašovat osnovy z 50. let 20 . století a podle nich učit, a je to dobře, ale rámcový koncept STEM je skutečně stejný. Takže jsme opět u (ne)poučení se z minulosti.

V úvodu příspěvku je uvedeno, že „přimět“ žáky studovat učňovské a technické obory lze „vnější" nebo „vnitřní" úpravou organizace školství, popř. i nějakým kompromisem. Cesta „vnější“ je jednoznačně rychlejší, jednodušší, ale omezující svobodu výběru vzdělávací dráhy jedince. Cesta „vnitřní“ se zdá býti z tohoto pohledu cestou lepší, ale výrazně pomalejší, s výsledky, jejichž efektivnost můžeme hodnotit až $\mathrm{v}$ horizontu např. 10 let. Nebudeme se po takové době ptát - koho zase budeme potřebovat? Nebudou technologie na takové úrovni, že tolik technicky vzdělaných lidí nebude potřeba? V kontextu stárnutí populace bude potřeba mnohonásobně více aktivizačních pracovníků pro práci se seniory. Co budeme v takovém př́padě měnit? Jak budeme intervenovat?

\section{Použitá literatura}

Janiš ml., K. (2014). Jak tedy reflektovat socialistickou pedagogiku. Pedagogická orientace, 24(1), 128-132.

Janiš ml., K. (2018). Kariérní řád - profesní rozvoj pedagogických pracovníků v reflexi dokumentu historického. Lifelong Learning, 8(3), 82-88.

Komenský, J. A. (1930). Velká didaktika. Praha: Dědictví Komenského.

Meisner, J. \& Veselý, M. (1951). Z diskuze o polytechnickém vzdělávání. Pedagogika, 1(9-10), 611-619.

Mejstř́ik, V., et al. (1975). Čeští učitelé na cestě k socialismu. Praha: SPN.

Podpora polytechnického vzdělávání: pojetí tematické oblasti v projektu P-KAP. Praha: NÚV. Dostupné z http://www.nuv.cz/uploads/P_KAP/ke_stazeni/pojeti_decizni_sfera/PTV_IV_ podrobne_pojeti_oblasti_intervence.pdf

Školy a školská zařízení - za školní rok 2016/2017. Praha: Český statistický úřad. Dostupné z https://www.czso.cz/csu/czso/skoly-a-skolska-zarizeni

\section{Autor}

Mgr. Kamil Janiš, Ph.D., Slezská univerzita v Opavě, Fakulta veřejných politik v Opavě,

Ústav pedagogických a psychologických věd, Bezručovo nám. 14, 74601 Opava,

e-mail: kamil.janis@fvp.slu.cz 